\section{Дмитро СКРИНЬКА}

\section{Технічні керівні настанови Всесвітньої митної організації: попередні рішення 3 питань класифікації, походження та оцінки (короткий огляд в контексті відповідних норм міжнародного права та законодавства України)}

\begin{abstract}
В статті міститься короткий огляд документу Всесвітньої митної організації, що має рекомендаційний характер. Підкреслюється факт тісного співробітництва Світової організації торгівлі та Всесвітньої митної організації, яке, серед іншого, сприяє більш ефективному виконанню положень Угоди СОТ про спрощення процедур торгівлі, в тому числі, відносно попередніх рішень. В статті вказується на принципову важливість попередніх рішень для підвищення ефективності державного регулювання міжнародної торгівлі. В статті міститься інформація про відповідні положення законодавства України.

Ключові слова: митниця, попередні рішення, митна вартість, спрощення процедур торгівлі, прозорість

The article contains a brief review of a World Customs Organization recommendatory document. It underscores the fact of close collaboration between the World Trade Organization and the World Customs Organization, which, inter alia, facilitates more efficient implementation of the provisions of the WTO Agreement on the Facilitation of Trade Procedures with regard to advance rulings. The article points out the fundamental importance of advance rulings for improving the efficiency of government regulation of international trade. The article contains information on the relevant provisions of Ukrainian legislation.
\end{abstract}

Keywords: customs, advance rulings, customs value, trade facilitation, transparency.

Останнім часом посилюється загальна тенденція розвитку міжнародного економічного права, яка полягає в пожвавленні процесів розробки і схвалення багатосторонніх та двосторонніх угод в тих сферах міжнародних економічних відносин, де відносно нещодавно міжнародно-правове регулювання було відсутнім або мінімальним.

Зокрема, серед відносно нових джерел міжнародного економічного права - Угода Світової організації торгівлі (СОТ) про спрощення процедур торгівлі (Угода СПТ), яка набула чинності в лютому 2017 року [2].

Світова організація торгівлі співпрацює з цілим рядом міжнародних організацій, зокрема, із Всесвітньою митною організацією (BMO). Співробітництво СОТ із ВМО можна структурно поділити на такі сфери як технічна допомога, гармонізація правил походження товарів, митна оцінка, торгівля товарами в сфері інформаційних технологій та спрощення процедур торгівлі.

Саме в сфері спрощення процедур торгівлі співробітництво між СОТ та ВМО було і залишається найбільш тісним і продуктивним.

УДК 341.6

(ㄱ Д. Скринька, 2019
СКРИНЬКА Дмитро Васильович

кандидат юридичних наук, доцент, доцент кафедри міжнародного права Київського національного університету імені Тараса Шевченка, Інститут міжнародних відносин 
Відтак, серед напрямів роботи ВМО - підготовка і публікація керівних настанов та інших документів, які мають на меті спростити для відповідних органів державної влади задачу запровадження стандартів діяльності, передбачених в Угоді СОТ про спрощення процедур торгівлі.

Так, наприклад, 26 липня 2018 року ВМО опублікувала оновлене видання Рамкових стандартів SAFE [5]. Ця нова редакція була схвалена Радою ВМО наприкінці червня того ж року. Документ містить базові міжнародні стандарти для забезпечення та сприяння глобальній торгівлі і зазвичай оновлюється кожні три роки. Першу редакцію документу було схвалено у 2005 році. Він містить сучасні стандарти безпеки ланцюгів поставок, знаменуючи собою початок реалізації нового підходу до комплексного управління процесом переміщення товарів через кордони, причому в документі визнається важливість більш тісного партнерства між митницями та підприємствами.

Версія 2018 року оновлює положення щодо співробітництва між митними адміністраціями, наприклад, через обмін інформацією, взаємне визнання заходів контролю, взаємне визнання уповноважених економічних операторів (УЕО) та взаємну адміністративну допомогу.

Звісно, питання спрощення процедур торгівлі не вперше стають предметом уваги міжнародної міжурядової організації. Більше того, цим питанням займалися і займаються й деякі міжнародні неурядові організації, зокрема Міжнародна торгова палата (МТП). Наприклад, можна згадати документ для обговорення (discussion paper) під заголовком «Оновлені рекомендації відносно угоди СОТ про спрощення торгівлі», опублікований МТП в 2007 році [1]. Документ було видано значно раніше моменту завершення переговорного процесу щодо цієї нової угоди СОТ і головна увагу в документі приділена формулюванню побажань до учасників переговорного процесу щодо змісту майбутньої угоди.

Зокрема, в тексті рекомендацій зазначено, що, з точки зору МТП, необхідно, щоб норми нової угоди про спрощення процедур торгівлі були достатньо ефективними для того, щоб спричинити таке поліпшення в системі заходів спрощення процедур торгівлі, яке піддавалося б вимірюванню.

Принагідно можна згадати, що в своєму нещодавньому дослідженні під заголовком «Індикатори спрощення процедур торгівлі. Потенційний вплив спрощення процедур торгівлі на торгівлю країн, що розвиваються» [4] Організація економічного співробітництва та розвитку (ОЕСР), зокрема, дійшла висновку про те, що саме система попередніх рішень (захід спрощення, передбачений статтею 3 Угоди СОТ про спрощення процедур торгівлі) здатна справляти найбільший вплив на скорочення витрат учасників торгівлі, порівняно з іншими заходами спрощення процедур торгівлі. Цікаво зауважити, що ОЕСР визначила 12 індикаторів спрощення процедур торгівлі, які, при застосуванні в цілому, потенційно можуть призвести до загального скорочення торговельних витрат на 10 відсотків. Але для попередніх рішень, як одного із заходів спрощення процедур торгівлі, вплив на торговельні витрати оцінюється ОЕСР як скорочення приблизно на 5,4 відсотка.

Найважливішими з числа всіх можливих тем попередніх рішень $є$ питання класифікації, походження та митної вартості товарів. Такі чинники, як, наприклад, ротація відповідних кадрових співробітників митної служби, можуть іноді призводити до непослідовності в практиці прийняття рішень митними органами. Відтак, міжнародна торговельна діяльність стає менш передбачуваною, оскільки вказані рішення впливають на суму мит, що підлягають сплаті, i, зрештою, на остаточну ціну продукту. Ця невизначеність може призвести до того, що ланцюги постачання перейдуть до країн з більшою визначеністю, передбачуваністю та надійністю, що вплине на розвиток міжнародної торгівлі в цілому.

Згадана стаття 3 Угоди СПТ, яка регулює питання попередніх рішень, містить деталізовані вимоги до держав-членів СОТ, які стосуються запровадження та функціонування попередніх рішень. Велику роль для практичного виконання положень цієї та інших статтей даної угоди відіграють рекомендації інших міжнародних організацій, зокрема, рекомендації Всесвітньої митної організації.

В контексті попередніх рішень на особливу увагу заслуговує документ ВМО під назвою «Технічні керівні настанови Всесвітньої митної організації: попередні рішення з питань класифікації, походження та оцінки» [3] (далі в тексті цієї статті - Керівні настанови) в редакції на червень 2018 року.

В пункті 5 цих керівних настанов недвозначно вказано, що вони «спрямовані на надання допомоги відповідним органам у практичному впровадженні та застосуванні програм в сфері попередніх рішень. Керівні настанови не є обов'язковими і не спрямовані на перегляд процедур, які вже створені або мають бути встановлені членами Організації».

Поняття попередніх рішень визначено в пункті 6 вказаних Керівних настанов (для цілей цих керівних настанов і відносно трьох категорій рішень) наступним чином:

- попереднє рішення про класифікацію, походження або оцінку є офіційним письмовим рішенням, виданим компетентним органом, який надає заявнику оцінку (i) класифікації товарів у номенклатурі митного тарифу відповідної країни або митної території; (ii) походження (в окремій 
виносці зазначається, що йдеться як про преференційне так і про непреференційне походження), або (iii) режиму, який має застосовуватися до певних складових вартості товару для визначення його митної вартості, до здійснення імпортної або експортної операції, причому таке рішення поширюється на визначений відрізок часу.

Крім того, в тому ж пункті містяться наступні важливі визначення:

- $\quad$ компетентний орган - митна адміністрація або призначений орган, відповідальний за видачу попередніх рішень;

- $\quad$ заявник - імпортер, експортер, виробник або будь-яка особа з обгрунтованою причиною звернення або його представник, який звернувся до компетентного органу для попереднього рішення щодо класифікації, походження чи оцінки.

Відносно поняття заявника в окремій виносці в тому ж документі цитується положення статті 3.9 (d) Угоди СОТ про спрощення процедур торгівлі, яка передбачає, що держава-член СОТ «може вимагати від заявника наявності законного представництва або реєстрації на його території. Наскільки це можливо, такі вимоги не обмежують категорії осіб, які мають право подавати заявки на отримання попередніх рішень, і окремо враховують особливі потреби малих і середніх підприємств. Такі вимоги повинні бути чіткими та прозорими і не становити засобу своєвільної або невиправданої дискримінації.

Основні положення Керівних настанов структурно поділені на 12 ключових сфер:

- інформація, що має бути включена до подання про попереднє рішення щодо класифікації, походження та оцінки товарів;

- порядок схвалення попередніх рішень про класифікацію, походження та оцінку товарів;

- порядок відхилення прохання про схвалення попереднього рішення та відкладення рішення з даних питань;

- правові наслідки попередніх рішень про класифікацію, походження та оцінку товарів;

- анулювання попередніх рішень про класифікацію, походження та оцінку товарів;

- внесення змін до, відкликання або визнання нечинними попередніх рішень про класифікацію, походження та оцінку товарів;

- правові наслідки внесення змін до, відкликання або визнання нечинними попередніх рішень про класифікацію, походження та оцінку товарів;

- $\quad$ ретроактивне застосування рішень про внесення змін до, відкликання або визнання нечинними попередніх рішень про класифікацію, походження та оцінку товарів;

- відкладене застосування рішень про внесення змін до або відкликання попередніх рішень;

- $\quad$ право перегляду в сфері попередніх рішень;

- $\quad$ право оскарження в сфері попередніх рішень;

- публікація попередніх рішень та конфіденційність інформації.

Варто окремо зупинитися на положеннях про порядок схвалення попередніх рішень про класифікацію, походження та вартість та про правові наслідки таких рішень.

Відповідно до пункту 13 Керівних настанов «Попередні рішення видаються у розумний, обмежений за часом термін після отримання заявки на попереднє рішення, за умови, що надана вся необхідна інформація. У випадку попереднього рішення про походження, як це вимагається в Угоді СОТ про правила походження, рішення повинно бути видане якомога скоріше, але не пізніше 150 днів».

Відповідно до пункту 14 Керівник настанов, попередні рішення щодо класифікації, походження та оцінки видаються заявнику в письмовій формі разом із зазначенням того, які дані будуть розглядатися як конфіденційні, а також із повідомленням про право перегляду та оскарження попереднього рішення.

Щодо конфіденційності рішень слід зауважити, що процедура попередніх рішень має враховувати необхідність дотримання балансу між потребами прозорості та потребами захисту конфіденційної інформації. Там, де це доречно, слід забезпечувати публікацію попереднього рішення для ознайомлення ділового співтовариства та інших зацікавлених осіб із положеннями відповідних попередніх рішень, але при цьому необхідно вживати адекватних кроків, щоб не допустити розголошення конфіденційної інформації.

Відповідно до пунктів 19-24 Керівних настанов попередні рішення щодо класифікації, походження та оцінки є обов'язковими, згідно з викладеними в ньому умовами, для органу, який видав попереднє рішення, відносно заявника, який його вимагав. Натомість, для цього заявника, якому було видано попереднє рішення, воно може бути обов'язковим. Попередні рішення набирають чинності 3 дати їх видання. Попередні рішення повинні містити дату, до якої вони залишаються чинними. Рішення залишається чинним щонайменше протягом одного року з дати видачі попереднього рішення, з урахуванням пункту 25 або 27 Керівних настанов. У випадку, якщо йдеться про походжен- 
ня товарів, відповідно до Угоди про правила походження, попереднє рішення залишається дійсним протягом трьох років, якщо факти та умови, включаючи правила походження, відповідно до яких рішення було схвалено, залишаються порівняними.

Окремо слід підкреслити значення пункту 24 Керівних настанов, який передбачає, що «попередні рішення можуть бути використані стосовно конкретного товару тільки тоді, коли встановлено, з точки зору органу, що прийняв попереднє рішення, що дані товари та обставини, які визначають їх класифікацію та походження, у всіх відношеннях відповідають тим, що описані в попередньому рішенні».

В пунктах 25-27 Керівних настанов зазначається, що попереднє рішення може бути анульоване, якщо воно було надане на підставі неповної, неправильної, сфальсифікованої або неправдивої інформації, наданої заявником.

Якщо відповідно до пункту 25 попереднє рішення анулюється, заявник, якому було видано попереднє рішення, має отримати повідомлення про це в письмовій формі. У цьому повідомленні повинні бути вказані відповідні факти та підстави для прийняття рішення.

Анулювання попереднього рішення діє з дати видачі попереднього рішення, а не 3 дати прийняття рішення про його анулювання.

Слід окремо згадати про законодавство України, яке передбачає підстави і порядок схвалення попередніх рішень.

Відповідно до пункту 1 статті 23 Митного кодексу України, «за письмовими зверненнями декларантів або уповноважених ними осіб органи доходів і зборів приймають попередні рішення щодо застосування окремих положень законодавства України з питань державної митної справи. Такі рішення виносяться до початку переміщення товарів через митний кордон України».

Пункт 4 тієї ж статті передбачає, що «Попередні рішення можуть прийматися 3 питань:

1) класифікації товарів (у тому числі комплектних об'єктів, що постачаються в розібраному стані декількома партіями протягом тривалого періоду) згідно з УКТ ЗЕД;

2) визначення країни походження товарів;

3) надання у випадках, передбачених цим Кодексом, дозволу на поміщення товарів в окремі митні режими».

Слід відзначити, що в статті 23 Митного кодексу України йдеться тільки про декларантів або уповноважених ними осіб, водночас Керівні настанови визначають, що заявник - це імпортер, експортер, виробник або будь-яка особа з обгрунтованою причиною звернення або його представник, який звернувся до компетентного органу для попереднього рішення щодо класифікації, походження чи оцінки.

Митний кодекс України не передбачає попередніх рішень щодо митної вартості. Звісно, Угода СПТ не вимагає, а лише рекомендує. щоб члени СОТ видавали попередні рішення щодо митної оцінки, але схвалення таких рішень здатне стати важливим позтивним чинником стабільності ланцюгів постачання товарів і чинником передбачуваності і прозорості національних регуляторних систем.

Основними підзаконними нормативними актами у сфері попередніх рішень є Наказ Міністерства фінансів України №650 від 30 травня 2012 року «Про затвердження Порядку роботи відділу митних платежів, підрозділу митного оформлення митного органу та митного поста при вирішенні питань класифікації товарів, що переміщуються через митний кордон України» та Наказ Міністерства фінансів України №737 від 19 червня 2012 року «Про затвердження Порядку прийняття, відкликання попереднього рішення про країну походження товару, затвердження форми попереднього рішення про країну походження товару».

Серед перспективних напрямів розвитку системи попередніх рішень можна виділити розширення тематики таких рішень, розробку і схвалення нормативних актів, які б зробили можливим схвалення попередніх рішень в сфері визначення митної вартості товарів. Це потенційно може призвести до значного поліпшення ефективності державного регулювання міжнародної торгівлі в Україні.

1. Updated ICC recommendations for a WTO agreement on trade facilitation. - Режим доступу: https:/ /cdn.iccwbo.org/content/uploads/sites/3/2003/04/ICC-recommendations-for-a-WTO-agreementon-trade-facilitation.pdf

2. WTO Agreement on Trade Facilitation. - Режим доступу: https://www.wto.org/english/docs_e/ legal_e/tfa-nov14_e.htm. Цитується за офіційним перекладом, розміщеним на сайті Верховної Ради України. -Режим доступу: https://zakon.rada.gov.ua/laws/show/981_053 
3. World Customs Organization Technical Guidelines on Advance Rulings for Classification, Origin and Valuation. - Режим доступу: http://www.wcoomd.org/-/media/wco/public/global/pdf/topics/ origin/instruments-and-tools/guidelines/guidelines-on-advance-rulings-for-classification-origin-andvaluation.pdf?la $=$ en

4. Trade Facilitation Indicators. The Potential Impact of Trade Facilitation on Developing Countries' Trade. - Режим доступу: https://www.oecd.org/dac/aft/TradeFacilitationIndicators_ ImpactDevelopingCountries.pdf

5. WCO Safe Framework of Standards (June 2018). - Режим доступу: /media/wco/public/ global/pdf/topics/facilitation/instruments-and-tools/tools/safe-package/safe-framework-of-standards. pdf?la=en

\section{Summary}

The article deals with advance rulings as one of the most effective trade facilitation measures, envisaged in the WTO Agreement on Trade Facilitation.

The article reviews the importance of the advance rulings in ensuring stability and predictability of the commercial regulatory environment.

The article mentions a document by the Organization for Economic Co-operation and Development (OECD), according to which advance rulings as a trade facilitation measure are capable of having the greatest impact on reducing the costs of traders, as compared to other measures to facilitate trade. It is noted that the OECD has identified 12 trade facilitation indicators, which, if applied as a whole, could potentially lead to a total reduction in trading costs by 10 percent. For advance rulings, as one of such trade facilitating measures, the impact on trade costs is estimated by the OECD as a reduction by about 5.4 per cent.

The key objective of advance ruling programs is to provide decisions on such issues as classification, origin and valuation of goods before their importation or exportation, thus adding certainty and predictability to international trade and helping traders to make informed business decisions based on legally binding rulings.

The World Trade Organization cooperates with a number of international organizations, including the World Customs Organization (WCO). WTO cooperation with WCO can be structurally divided into such areas as technical assistance, harmonization of rules of origin of goods, customs valuation, trade in goods in the field of information technology and trade facilitation.

The collaboration between the WTO and the WCO in the area of trade facilitation has been the most close and productive.

Among the areas of work of the WCO is the preparation and publication of guidelines and other documents, aimed at simplifying the task for the relevant public authorities to implement the standards of the WTO Agreement on Trade Facilitation.

The article focuses on the review and brief analysis of the World Customs Organization Technical Guidelines on Advance Rulings for Classification, Origin and Valuation (as of June 2018). The article underlines the recommendatory character of the Technical Guidelines, but also stresses the usefulness and importance of this document.

The article indicates the structure of the Technical Guidelines, which is based on the following list of issues:

- Definitions and scope

- Application for advance rulings on classification, origin and valuation

- Issuance of advance rulings on classification, origin and valuation

- Declining and postponing issuance of advance rulings on classification, origin and valuation

- Effect of advance rulings on classification, origin and valuation

- Annulment of advance rulings on classification, origin and valuation

- Modification, revocation or invalidation of advance rulings on classification, origin and valuation

- Effect of modification, revocation or invalidation

- Retroactive application of modification, revocation or invalidation

- Postponed application of modification or revocation

- Right of Review

- Right of Appeal

- Publication and confidentiality

With regard to the effect of the advance rulings it is pointed out in the article that advance rulings on classification, origin and valuation shall be binding, in accordance with the terms set out therein, on the 
authority that issued the advance ruling in respect of the applicant that sought it. However, the advance rulings may be binding on the applicant to whom the advance ruling was issued.

The article mentions the key regulations on advance rulings in Ukraine (Order of the Ministry of Finance No. 737 «On Approval of the Procedure for the Issue and Revocation of the Advance Ruling on Origin of Goods» of 19 June 2012 and Order of the Ministry of Finance No. 650 «On Approval of the Operating Procedure of the Customs Duties Department, Customs Clearance Department of the Customs Authority and the Customs Post regarding the Classification of Goods Transported through the Customs Border of Ukraine» of 30 May 2012) and deals with the issue of possible expansion of the scope of application of the advance rulings to include the issues of customs valuation of goods. 